\section{BESZÁMOLÓ A MABISZ 2016. NOVEMBER 21-ÉN TARTOTT KONFERENCIÁJÁRÓL}

Lencsés Katalin (Magyar Biztositók Szövetsége), katalin.lencses@mabisz.hu

\section{ÖSSZEFOGLALÓ}

A MABISZ 2016 novemberében tartotta VII. konferenciáját. Az idei rendezvény középpontjában a környezettudatosság, a fenntartható fejlődés és a klímaváltozás állt. Jelen beszámoló erről az eseményről ad összefoglalót.

\section{SUMMARY}

The Association of Hungarian Insurance Companies (MABISZ) held its 7th conference in November 2016. This year the event focused on environmentalism, sustainable development and climate change. This article gives the summary of the conference.

\section{Kulcsszavak: biztosítás, konferencia}

Keywords: conference, insurance

\section{JEL: G22}

DOI: $10.18530 /$ BK.2017.1.98

http://dx.doi.org/1018530/BK.2017.1.98
A Magyar Biztosítók Szövetsége 2016. november 21-én tartotta VI. konferenciáját a Corinthia Hotel Budapestben. A biztosítási szektor legnagyobb konferenciája ismét kiváló alkalmat jelentett a biztosítók, a velük együttműködő vállalkozások, a szabályozói és felügyeleti döntéshozók képviselői számára a magas szintű szakmai eszmecserére.

A konferenciát a MABISZ fötitkára, Molnos Dániel nyitotta meg röviden megelőlegezve a nap előadásait.

Az első előadó Hornung Ágnes, a Nemzetgazdasági Minisztérium pénzügyekért felelős államtitkára volt, aki előadásában összefoglalta az elmúlt egy év fontosabb gazdasági fejleményeit. A gazdasági növekedés mértéke és szerkezete egyaránt megnyugtató módon alakult, a foglalkoztatottság rekordsebességgel emelkedett. További ösztönző megoldások is kilátásban vannak, melyeknek része a minimálbérek emelése, illetve a további járulékcsökkentés. A GDP-arányos államadósság is csökkenő pályán van, így indokolt az optimista előretekintés.

A pénzügyi válság a biztosítókat is érintette, a gazdasági visszaesés ebben a szektorban is megmutatkozott. 2015-töl azonban ismét növekedés tapasztalható, ami a biztosítások gazdaságban betöltött pozitív szerepe miatt is fontos fejlemény.

A jogszabályi környezetre áttérve az előadó elmondta, hogy az aktuális Bit. módosítások az ügyfél-tájékoztatás garanciális szabályaira és az etikus életbiztositási koncepció elemeire irányultak. Egyes elemek már 2016-ban életbe léptek, míg több rendelkezés 2017-től lesz hatályos. Az államtitkár a kormány és a biztosítási szektor közös feladataként azonosította az öngondoskodás ösztönzését, mivel a lakosság nagyobb része még mindig nem eléggé tudatosan kezeli a pénzügyeit. Szó esett végül a következő év feladatáról is, ami az új, európai uniós biztosítási értékesítési irányelv (IDD) implementálása.

A konferencia második előadója Szabó Zsolt, a Nemzeti Fejlesztési Minisztérium fejlesztésés klímapolitikáért, valamint kiemelt közszolgáltatásokért felelős államtitkára volt. Előadását azzal a felütéssel kezdte, hogy habár általános tendenciaként figyelhető meg a hőmérséklet növekedése és az időjárási szélsőségek gyakoribbá válása, a klímaváltozásról a vélemények még mindig eltérőek. Ugyanakkor jobb előre felkészülni, és erre szolgál a párizsi megállapodás, amely konkrét kibocsátáscsökkentési célokat állított fel. Az Európai Unión belül célként került meghatározásra az üvegházhatású gáz 40 százalékos csökkentése, a megújuló energia részarányának 27 százalékra növelése, valamint az indikatív 27 százalékos energiahatékonysági célszám elérése.

Magyarország valamennyi említett vonatkozásban időarányosan jól áll. A második Nemzeti Éghajlatváltozási Stratégiát benyújtották az Országgyülés elé, és készül a cselekvési terv is. A kormány célja, hogy a klímaszabályozásban gazdaságilag is érdekeltté tegye az érintett szereplőket. Az elkövetkező időszakban a téma egyre inkább fogja érinteni a biztosítási területet is. A felmerülő kérdések és problémák közös kezelését segítendő a minisztérium szakemberei országos hálózatban állnak rendelkezésre. 
A kávészünetet követően a konferencia Windisch László MNB alelnök előadásával folytatódott. 2013 óta az MNB égisze alatt a felügyelési tevékenység egyfaita paradigmaváltáson ment át, melynek része a piacokon a „fair” szemlélet erősítése, a szigorú, de konzultatív felügyeleti magatartás, az előretekintő megközelítés és a digitalizációs fordulat. Ez utóbbi területen az egyik legnagyobb lépést a 2018-tól bevezetésre kerülő elektronikus kapcsolattartás fogja jelenteni.

2016-ra előzetesen a biztosítók a növekedés lehetőségét a nyugdíj-, lakás- és gépjármü-biztosításokban, valamint a kkv-szektorban látták. Fő kihívásnak pedig a Szolvencia II-es feladatokat, az alacsony hozamkörnyezetet, a digitalizációt és az etikus koncepciót gondolták. A növekedési remények közül egyedül a kkv-szektorral kapcsolatos várakozások nem teljesültek. Az évközi adatok alapján úgy látszik, hogy a biztosítók jó évet zárhatnak a díjbevétel, a nyereség és a tőke növekedésének vonatkozásában egyaránt. Folytatódik a díjövekedés trendje, 2016 első félévében 3,5 százalékos volt a növekedés az előző év azonos időszakához képest, az előrejelzések szerint pedig a szektor 2018-ra elérheti a 900 Mrd Ft-os díjbevételt. A jövedelmezőségi adatok szintén pozitív képet mutatnak a 2015 előtti évekhez képest, a jövőben ugyanakkor kihívást jelent az alacsony hozamkörnyezet és az etikus koncepció átmeneti hatása. A szektor tőkehelyzete stabil, a tőkefeltöltöttség 200 százalék fölött van.

A szakma egyik sikertörténete a nyugdíjbiztosítás, melynek aránya már 13 százalék a rendszeres díjas termékek körében. A termékcsoportot a hosszú tartam, magas átlagdíj és a kiváló megmaradás jellemzi. A nem-életbiztosítások vonatkozásában a kgfb és a lakossági vagyonbiztosítások nőttek az elmúlt időszakban (22,7,ill. 7,7\%-kal), míg a vállalati vagyonbiztosítások csökkentek (2,7\%). Pozitív fejlemény, hogy a kgfb termék esetében végre 100 százalék alatt van a kombinált mutató, amivel a termékcsoport kikerült a magas kockázatú körből. A rendszer költséghatékonyan működik, és továbbra is élénk verseny várható. Az előadó szerint a jövőben az okos, szegmentáción alapuló árazás kerül előtérbe.

\section{A szakma egyik sikertörténete a nyugdíjbiztosítás.}

A Szolvencia II kapcsán elhangzott, hogy a hazai szabályozás európai összehasonlításban is sikeres, az EIOPA felé teljesített SII adatszolgáltatás 100 százalékos lefedettségű, és jelentős validációs hiba nélkül teljesült. A biztosítók háromnegyedének tőkefeltöltöttsége 150 százalék fölött van, fele 200, két biztosító pedig 300 százalék fölött. A következő időszak kihívása ugyanakkor, hogy a tartósan alacsony hozamkörnyezet piaci sokk esetén akár a hagyományos portfóliókat is veszélyeztetheti.

A konferencia vezető témájához kapcsolódóan a hallgatók azt is megtudták, hogy jelentős tétel a katasztrófakockázat szavatolótőke-szükséglete, ami a teljes nem-élet szavatolótőke-szükséglet 35 százalékát teszi ki. A klímaváltozás mindenkit érint, egyaránt jelent fizikai, átállási és felelősségi kockázatot.

Az előadás kitért az etikus koncepcióra is, amely az életbiztosítások termékfejlesztését célozza terelni. A koncepció elemei az átláthatóság növelése, a fair ár-érték arány biztosítása, szigorú befektetési szabályok és a félreértékesítések csökkentése. A szabályozás által elvárt csökkenő
TKM értékektől az MNB azt várja, hogy csökken a törlések aránya, ami javítja a termékek profittermelő képességét, akár csökkenő értékesítés mellett is. Kiemelésre került, hogy a legrosszabb gyakorlatnak a Felügyelet a többi piaci szereplő állományának a „kannibalizálását” tartja. Végül szó esett a fogyasztóbarát szolgáltató koncepcióról is, melynek kapcsán az MNB fontolóra vette egy védjegyrendszer bevezetését is.

A nap első felének programját a MABISZ elnökének előadása zárta. Pandurics Anett szintén a piac 2016 első félévének az összefoglalásával kezdte. Folyatódott a 2013-ban elindult trend, és a biztosítási piac ebben az időszakban 5,4 százalékkal növekedett, a növekedés mindkét ágat érintette. Az előző előadást kiegészítve arra is rámutatott, hogy a kgfb-piac még mindig nem érte el a válság előtti díjszintet. Az életbiztosítások vonatkozásában kiemelte, hogy a folyamatos dijas életbiztosítási bevétel örvendetes módon 4,2 százalékkal nőtt. A termékcsoporton belül megkerülhetetlen a nyugdíjbiztosítások előremutató és pozitív szerepe, ezt igyekezett megerősíteni a MABISZ által lebonyolított nyugdíjbiztosítási kampány is.

Ez az előadás is kitért az etikus életbiztosítási koncepcióra, részletesebben is megvilágítva annak hátterét, hogy miért volt szükség az életbiztosítások új szabályaira. A befektetési termékek több szempontból is egyedi sajátossággal bíró termékeknek tekinthetőek. A biztosítás szempontjából különösen kiemelt jelentőségű, hogy nem jellemző a független bevásárlás, meghatározó a tanácsadás és bizalom jelentősége az ügyfélkapcsolatban. Többek között ezért is indokolt a szabályozás egységesítése mind a szolgáltatók, mind pedig a csatornák vonatkozásában. Erre hazai válasz az etikus életbiztosítási koncepció, melyről az előző előadó részletekbe menően is tájékoztatott, a kapcsolódó európai fejleményeket pedig az IDD irányelv és a PRIIPs rendelet jelentik. Mindkét esetben fókuszban vannak a befektetési termékek, ezen belül is az értékesítési folyamat szabályozása és az ügyfél-tájékoztatás megerősítése, illetve egyszerűsítése. Ez utóbbit érintően két, rövid standard ügyféldokumentum is alkalmazásra kerül 2018-tól, az életbiztosítások esetében a KID (Key Information Document), a nem-életbiztosításoknál pedig a PID (Product Information Document).

\section{A káresetek szaporodása várható, ami elkerülhetetlenné teszi} a kockázatkezelés új alapokra helyezését.

A konferencia vezető témájára áttérve az előadó elmondta, hogy a természeti kockázatokkal kapcsolatos kockázatmenedzsment a biztosítási szektor alapvető feladata és kompetenciája, így nem meglepő, hogy a biztosítási szektor a kezdetektől aktív résztvevő a klímaváltozás hatásainak modellezésében és a megoldási lehetőségek feltárásában is. Az előadás ezt az állítást több ténnyel és adattal is alátámasztotta, külön kitérve a klímaváltozás várható hatásaira a magyar biztosítási piacon. Ezek a hatások komoly kihívások elé állíthatják a hazai biztosítókat, elsősorban a vagyonbiztosítások (ezen belül kiemelten a lakásbiztosítások), a mezőgazdasági biztosítások, illetve egyes szakmai felelősségbiztosítások kapcsán. Ezeken a területeken a káresetek szaporodása várható, ami elkerülhetetlenné teszi a kockázatkezelés új alapokra helyezését. 
A délutáni szekció első vendégeladója Thomas Hlatky, az osztrák GRAWE Biztosító viszontbiztosítási vezetője volt, aki a természeti katasztrófákról, illetve azok kockázatkezeléséről beszélt a változó klímakörnyezetben. Megtudhattuk, hogy az európai megoldások jelentős különbségeket mutatnak, de abban mindegyik közös, hogy a biztosíthatóság alapelvére épülnek. Négy országcsoport konkrét rendszerét is bemutatta az előadó. Ezen a piacon fordított arányosság áll fent a kereslet és a kínálat között. Az önkéntességen alapuló biztosítási piac nem tud megfelelö fedezetet ajánlani a magas kockázatot képviselő területek számára. A díjak és a fedezetek egyaránt magas volatilitást mutatnak, jelen vannak továbbá a biztosítási fedezet elterjedése szempontjából kontraproduktívnak tekinthető megoldások is (pl. állami alapok). Az előadó a fentiek illusztrálására konkrét adatokat is bemutatott. Ebben az előadásban is megerősítésre került, hogy a biztosítók szerepe szükségszerüen növekszik a klímaváltozások nyomán a kockázatáthárítás, kockázatértékelés és prevenciós feladatok kapcsán egyaránt. Nem könnyíti meg a helyzet átfogó kezelését ugyanakkor az, hogy a biztosítási fedezetek eltérőek az egyes európai országokban, mások a feltételek, más a biztosítási esemény definíciója, és eltérő a kárrendezés menete. A jövőbe mutató megoldások kapcsán megkerülhetetlen az Európai Bizottság szerepe, annak ösztönzése, hogy megfelelő nemzeti stratégiák és rendszerek legyenek a természeti katasztrófák kezelésére, melyeknek alapját képezhetik a már meglévő megoldások és jó gyakorlatok.

A következő előadás egy kutatás eredményét foglalta össze, amelyet a Századvég Alapítvány készített 1000 fôs országos mintán. Hídvégi Âron közvélemény- és piackutatási igazgató ennek alapján azt mutatta be, hogy mit gondolunk a klímaváltozásról. Ebben a vonatkozásban úgy tűnik, megvan a lakossági tudatosság, mivel csak 2 százalék véli úgy, hogy a klímaváltozás problémája egyáltalán nem aggasztó, és a többség már most, de maximum 10 éves távlatban érzékelhetőnek látja ennek hatásait. A megkérdezettek 22 százaléka hisz abban, hogy a klímaváltozás megállítható és visszafordítható, míg 53 százalék szerint megállítható ugyan, de már nem visszafordítható. A klímaváltozás elleni küzdelemben a 46 százalékot képviselő relatív többség azállamnak szán vezető szerepet, 27 százalék szerint ezt a vállalatoknak kell vállalniuk, míg 18 százalék szerint a lakosságnak. A válaszadók mindössze 8 százaléka gondolja úgy, hogy mindenkinek szerepet kell vállalnia ebben a küzdelemben. A minta túlnyomó többsége úgy gondolja, hogy ő személy szerint hozzájárul valamiképpen a klímaváltozás megelőzéséhez. Az is kiderült továbbá a felmérésből, hogy a lakosság a biztosítások szerepét is fontosnak látja a természeti károk kezelésénél, bár az adatok nem éppen ezt támasztják alá, ugyanis a viharkárok kivételével a többség nem rendelkezik biztosítással a megnevezett természeti káreseményekre.

A konferencia első kerekasztal-beszélgetése a klímaváltozás biztosítási piacokra gyakorolt hatását járta körbe. A kerekasztal-beszélgetés résztvevői voltak: Bérczi László tűzoltó dandártábornok, BM Országos Katasztrófavédelmi Főigazgatóság; Ilics László vezérigazgató-helyettes, Generali Biztositó; Szalai Péter ügyvezető, PEND Consulting; Vereczki András Lakossági nem-életbiztosítási és Kárrendezési vezető; moderátor: Bárczay András szakértő, Allianz Hungária Biztosító.
Indításként elhangzott, hogy az éghajlatváltozás miatt már látható jelei vannak a klímaváltozásnak, ami a biztosítások vonatkozásában is érezteti hatását. Az elmúlt években a kárkép is mutatja, hogy a heves viharok, az átlaghőmérséklet emelkedése, a csapadékviszonyok változása másfélszeresére növelte a kárgyakoriságot, és éves szinten akár 30 milliárd forinttal is csökkenhet a profitszint a károkon keresztül.

\section{A kockázatokra egyrészt kihívásként, másrészt lehetőségként kell tekintenie a szakmának.}

A biztositók egyik legfontosabb feladata, hogy pontosan felmérjék, milyen típusú károk várhatók, és a kockázatokat milyen termékekkel lehet fedezni. A kockázatokárazásához a megfelelő információs rendszerek müködtetése elengedhetetlen. A biztosítók tapasztalata szerint nem a károk mértéke, hanem az intenzitása változott meg. A fogyasztói igényeknek megfelelő gyors és hatékony kárrendezés jogos elvárás a biztositók felé. A biztosítók egyik legfontosabb feladata, hogy pontosan felmérjék, milyen típusú károk várhatók, és a kockázatokat milyen termékekkel lehet fedezni. A kockázatok árazásához a megfelelő információs rendszerek működtetése elengedhetetlen. A biztosítók tapasztalata szerint nem a károk mértéke, hanem az intenzitása változott meg. A fogyasztói igényeknek megfelelő gyors és hatékony kárrendezés jogos elvárás a biztositók felé. A kockázatokra egyrészt kihívásként, másrészt lehetőségként kell tekintenie a szakmának, és ezekre alaposan fel kell készülni. De nem kevésbé fontos a kármegelőzés, a kockázatcsökkentés sem, melyhez szükséges a lakosság edukációja is, a környezettudatosság, a megfelelö ismeretek elsajátítása a környezeti károk elleni védekezéshez.

Az Országos Katasztrófavédelmi Főigazgatóság az elmúlt években aktív kommunikációt folytatott a károk megelőzése terén, kiemelten a tűzesetek, müszaki mentések vonatkozásában. Fel kell készülni olyan természeti eseményekre is, amelyek eddig nem voltak, mint például a ciklon. 2015-ben az ónos eső miatt mintegy 1000 riasztás történt, Dobogókőt nem lehetett megközelíteni, sorra dőltek ki a fák. A tűzoltóságok felszereltségét, eszközeit is ezekhez a feladatokhoz igazítják, amihez a finanszírozási források a kormány részéről és EU-támogatásból is biztosítottak. 2012 óta új felállásban működik a katasztrófavédelem, elvégezték a települések kockázati besorolását 1-3 szintre bontva, elindították a monitoring lakosságriasztó rendszert is.

A biztositók képviselői úgy vélték a beszélgetés során, hogy az egyes biztosítási üzletágakat a klímaváltozással járó kockázatok eltérően érintik, ezért egyedi, részletes kockázatelbírálást kell végezni, de tudományos előrebecslések is segíthetik a biztosítók kockázatvállalását. Nagyon fontos az ajánlatok befogadásához, hogy a kockázatvállalók megfelelő műszaki, technikai ismeretekkel rendelkezzenek.

A tapasztalatok azt mutatják, hogy a klímaváltozással összefüggésben feloyorsult a technológia fejlődése is, ami a biztosításokra is hatással van. Például a biogázzal működő erőművek esetében eltérhet a géptörés-biztosítás a más technológiával működő erőművek gépbiztosításaihoz képest.

A kerekasztal-beszélgetés résztvevői külön kiemelték a klímaváltozás hatását a lakásbiztosításokra nézve. Nemzetközi példák vannak arra, hogy a szektor érintettségét hogyan lehet 
vizsgálni, ilyen kutatásokat, felméréseket végeztek Floridában, Németországban, Angliában. Magyarországon a lakásállomány korszerüsítése fóként az energetikai/szigetelési feladatok teljesítését jelenti. Mindenképpen az épületek szél- és vízellenálló képességének növekedésére kell törekedni. A lakosság saját erőből történő beruházásai, az állami szerepvállalás mellett a biztosítóknak is van feladatuk. A konferencia napján jelent meg a tervezői-kivitelezői felelősségbiztosításról szóló rendelet, melyben az elöírtaknak megfelelő termékeket a biztosítóknak kell a tervezők, kivitelezők rendelkezésére bocsátani.

A biztosítás a kockázatkezelés egyik eszköze, de a lakosság szemében a biztosítás a „szorongásokat" is csökkenti. Ezt nem szabad figyelmen kívül hagyni, amikor a termékeket értékesítik a biztosítók. Az ügyfélkapcsolatok erősítése, a valós asszisztencia, azaz az ügyfél mellett állni, amikor kár éri ôt - minden biztosítónál kiemelt célkitűzés. A kerekasztal-beszélgetés végén a résztvevők elmondták, hogy a biztosítási szektor a változásokkal együtt is meg tud felelni a kihívásoknak. Kiemelten fontos továbbá a közös gondolkodás a jogalkotóval, az együttműködés az állami döntéshozók és a biztosítók között, amihez a szakma minden tapasztalatával hozzá kíván járulni.

Rövid kávészünetet követően a konferencia a biztosítás jövőjével folytatódott. Kerekes Antal, a PricewaterhouseCoopers Magyarország partnere abba nyújtott betekintést, hogy milyen változásokat hoz a technikai forradalom a biztosítók életében. A biztosítók hagyományos üzleti modelljét a globális trendek befolyásolják (társadalmi és technológiai változások, szabályozás, klímakörnyezet stb.). Ennek következtében alapvető kérdéseket kell újragondolniuk a biztosítóknak: kinek, mit és hogyan fog fenntartható módon szolgáltatni aziparág.

A „kinek” kérdésre a válasz, hogy már nem ugyanazokat az ügyfeleket kell kiszolgálni, mint 100 éve. 2020 után várhatóan már az ún. digitális bennszülöttek fogják dominálni a keresleti piacot, így a globális fogyasztói trendek (internet és mobilhasználat) nem kerülik el Magyarországot sem. Kulcsfeladat tehát a fogyasztó jobb megismerése, annál is inkább, mivel a fogyasztók tudatosabbá váltak, és alternatív módon veszik igénybe a biztosítási szolgáltatásokat is. Fogyasztói közösségek jönnek létre, amelyek tömeges terméket vesznek, a biztosító mint közösségszervező háttérbe szorul.

A „mit” kérdésre választ keresve az került kiemelésre, hogy a biztosítási piacot felforgató folyamatok egyben lehetőséget teremtenek új biztosítási szolgáltatások kialakítására. A tulajdonhoz való viszony megváltozása, a megosztáson alapuló modellek (shared economy) új kockázatokat és üzleti modelleket eredményeznek, ami szintén új kihívás a biztosítók irányában. Tovább folytatva a sort, a technológiai robbanás eddig elképzelhetetlen üzleti és teljesen új felelősségi modelleket teremt. Elég, ha csak a Big Data analitikára vagy az okos hálózatokra gondolunk. Az egészségbiztosítási piac növekedését a demográfiai változások, az állami egészségügyi rendszerek problémái és az egészségtudatosság fogják hajtani. Az élet- és nyugdijbiztosítások tekintetében pedig az új technológiák az átláthatóság növelését és az elosztási csatornák hatékonyságát befolyásolják.
A „hogyan” kérdés megválaszolásához a teljes működés mentén hatékonyságjavulásra van szükség, amiben kulcsszerepet kap az új technológiák kihasználása (digitális eszközök, adatelemzés stb.). Számos biztosító indított már kezdeményezéseket abból a célból, hogy felvegyék a kesztyűt a digitális versenyben. Sok azonban még a teendő, meg kell találni az inkumbensek útját, hogyan akarnak viszonyulni a biztositók az új belépőkhöz és akár digitális belső versenytársaikhoz.

És végül a fenntarthatóság mint alapvető ügyfélelvárás került kihangsúlyozásra, aminek meg kell tudni felelni mind a belső működés, mind pedig a piaci szerepvállalás tekintetében.

A konferencia hátralévő részében elöször a Századvég egy másik kutatásával ismerkedhettek meg a konferencia résztvevői. Hídvégi Áron a lakosság hosszú távú megtakarítási attitűdjeiről tartott ismertetést. A megkérdezettek 45 százaléka saját bevallása szerint egyáltalán nem takarít meg, 30 százalék csak esetenként, míg 22 százalék számolt be rendszeres megtakarításról. A megtakarítások jellemző módon vésztartalék ként szolgálnak (45\%), és csak 6 százalék válaszolta, hogy nyugdíjcélra tesz félre. A megtakaritások zömét 5 évnél rövidebb távra szánják, ennél hosszabb időtartamról csak a megkérdezettek 34 százaléka számolt be. A többség (66\%) még mindig az államtól várja a nyugdijkori ellátást annak ellenére, hogy szintén a többség nem igazán tartja hosszú távon fenntarthatónak a jelenleg müködő állami nyugdíjas rendszert. A nyugdíjbiztosítás fogalmát az emberek jórészt nem tudják megfelelő módon definiálni. A megkérdezettek ugyanakkor csak mintegy fele-fele arányban tartják problémának, hogy ezeknél a termékeknél csak a nyugdijkorhatár elérése után lehet hozzáférni a megtakarításhoz. Komoly ellentmondást feszeget a következő két kérdésre adott válasz. Eszerint a meghatározó többség havi 300 ezer forintnál többet tart szükségesnek a jelenlegi életszínvonala fenntartásához, rendszeres járadékfizetéssel, ugyanakkor mindössze 24 százalék lenne hajlandó havi 20 ezer forintnál többet kifizetni nyugdíjbiztosításra.

A rendezvény utolsó programja egy kerekasztal-beszélgetés volt, mely az etikus életbiztosítási koncepció és digitalizáció kérdését vitatta meg. (Résztvevők: Garamvölgyi Zoltán ügyvezető igazgató helyettes, GROUPAMA Biztosító, Juhos András igazgatósági tag, UNIQA Biztositó, Kozek András vezérigazgató-helyettes, Allianz Hungária Biztosító, Nagy Koppány igazgató, Magyar Nemzeti Bank. Moderátor: Bartók János igazgatósági tag, ERGO Biztosítási Csoport.)

A beszélgetés azzal indult, hogy a fenntarthatóság kérdésének boncolgatásakor nem lehet megkerülni a biztosítás értékesítésének a kérdését. Az MNB képviselöje azt hangsúlyozta, hogy a hosszú távú fenntarthatóság az ügyféligény-alapú értékesítést követeli meg, ezt irányozza az etikus életbiztosítási koncepció is, melynek középpontjában a szerződések megmaradása áll. Amennyiben nő a portfólió élettartama, az hosszú távon növeli a díjbevételt, és stabilizál még az átmenetileg visszaeső profitabilitás mellett is, és egyben biztosítja a költséghatékonyabb működést. A változás az alacsony hozamkörnyezetben gazdasági szükségszerűség, és nem önmagáért való szabályozói törekvésről van szó. A nyugdíjbiztosításoknak például ki kell kerülniük az általános megítélés alól, ami ezeket a termékeket a drágasággal azonosítja a többi 
nyugdijtermékkel szemben. A juatalékmodellek kapcsán felmerülhet az a lehetőség is, hogy másnak kellene kezelnie az állományt, mint aki megszerzi, mivel mindkét tevékenység másfajta készség meglétét igényli.

A biztosítói oldal hangsúlyozta, hogy a piac már eddig is sokat tett azért, hogy jó ár-érték arányú termékek kerüljenek a piacra. Aki a korábban vásárolt termékét hosszú távon megtartotta, nem járt rosszul, a probléma inkább az volt, hogy az átlagos megtartás nem érte el a 7 évet. Ennek okait érdemes vizsgálni, de az állékonyság javításában sokat segíthet a nyugdíjbiztosításokra nyújtott adókedvezmény is, az első tapasztalatok pozitívak. A szabályozónak ugyanakkor arra is figyelnie kell, hogy a közvetítők ne tünjenek el a piacról, mivel a személyes eladás szerepe továbbra sem lesz megkerülhető a megtakarítási termékeknél. A bevezetett TKM maximumok önmagukban is jutalékkorlátozást jelentenek, ami komoly kihívást jelent a hagyományos csatornák számára. Az alacsony hozamkörnyezet miatt amúgy is elvárt, hogy nőjön a piac versenyképessége. Hosszú távú választóvonal, hogy mely befektetési eszközök maradnak meg a piacon. Fontos, hogy a biztosítási termékek a palettán maradjanak. Ez a kényszer rövid távon ugyan kihívást jelent, hosszú távon azonban segíti a szakma reputációjának a javítását. Az MNB korábbi felvetésével vitatkozva az is elhangzott, hogy nem szükséges az állományt mással múködtetni, a biztosítói tapasztalat ugyanis az, hogy a jól felkészült értékesítő mindkét feladatot el tudja látni.

\section{Hosszú távú választóvonal, hogy mely befektetési eszközök maradnak meg a piacon.}

A digitalizáció témakörére áttérve azt vitatták meg a résztvevők, hogy kinek mi jut először eszébe erről a szóról a biztosítási piac vonatkozásában. Manapság amint adathoz jut egy biztosító, az azonnal bekerül az online rendszerbe, ami a költséghatékonyság elérésében is sokat segít. Sok helyen a honlapok átalakítják az értékesítést, az életbiztosítások vonatkozásában azonban ez a folyamat sokkal lassabban fog végbemenni. Itt a személyes eladás szerepe még sokáig fenn fog maradni. A digitalizációból fakadó papírmentesség szintén szerepet játszik a költséghatékonyabb működésben, és egyben segítséget jelenthet a közvetítő számára is. Továbbá és nem utolsósorban a digitalizáció élményt is nyúit, melyet érdemes kihasználni. Segít abban, hogy a biztosító ügyfélre szabott ajánlattal jelenjen meg, a honlapok megfelelő marketingjének a költsége összemérhető a közvetítői javadalmazással.

A kép árnyalása érdekében felvetődött az is, nem biztos, hogy minden értékesítés elmegy a digitális megoldások irányában. Példaként az oktatás merült fel, ahol a közös szociális tér meglétének igénye felülírja az online megoldások hatékonyságát.

A közös gondolkodást provokálandó levetítettek egy kisfilmet a Lemonade alkalmazásról. Az a korosztály, amelyik ezt használja, már másképpen gondolkodik, másfajta kommunikációt és kezelést igényel. Valóban, egyre értékesebb számukra a közösségi, digitális kommunikáció, ugyanakkor ennek a generációnak az időtávja is egyre rövidebb, egyre nehezebb számukra a hosszú távú döntések meghozatala, miközben ezen döntések nagy fontossággal bírnak. Valódi kihívást jelent, hogyan tudják ezt a feladatot az életbiztosítók megoldani.

A téma kapcsán megkerülhetetlenül szó esett a különböző alkalmazásokról (appok). Ezeknek lehet szerepük akár a nyugdíjbiztosítások vonatkozásában is, ugyanakkor inkább a kárrendezésnél kerülnek képbe, és nem a szerződéskötéseknél. Az alkalmazások a pörgős környezetben inkább a figyelmet tudják megragadni, és segítenek az első lépés megtételekor. Van tehát szerepük az online megoldásoknak az igényfelkeltésben és tudatosításban.

Összegzésként végül elhangzott a moderátor részéről, hogy a mit és hogyan kérdésre születnek válaszok, arra azonban még nem, hogy miért teszik a piaci szereplők azt, amit tesznek. Jó lenne megfordítani a sorrendet, és a miért kérdésre is megtalálni a jó válaszokat.

Az eseményt a MABISZ főtitkára, Molnos Dániel zárta, kifejezve reményét, hogy a résztvevők számára tartalmas és gazdag programot kínált a nap, és egyben rögzítette annak fontosságát, hogy a biztosítók, a döntéshozók, illetve a felügyeleti szervek képviselői a jövőben is folytatják a konstruktív együttgondolkodást a hazai biztosítási piac és az ügyfelek érdekében.

Az érdeklődők az előadások anyagait a MABISZ konferencia honlapján megtalálják: http://mabiszkonferencia.hu/ 